Saint Louis University School of Law Scholarship Commons

All Faculty Scholarship

2013

\title{
Strange Traffic: Sex, Slavery \& the Freedom Principle
}

Anders Walker

Saint Louis University School of Law

Follow this and additional works at: https://scholarship.law.slu.edu/faculty

Cart of the Criminal Law Commons, $\underline{\text { Criminal Procedure Commons, and the Sexuality and the }}$ Law Commons

\section{Recommended Citation}

Walker, Anders, Strange Traffic: Sex, Slavery \& the Freedom Principle (February 19, 2013). Connecticut Law Review, Vol. 46, No. 2 , 2013.

This Article is brought to you for free and open access by Scholarship Commons. It has been accepted for inclusion in All Faculty Scholarship by an authorized administrator of Scholarship Commons. For more information, please contact erika.cohn@slu.edu, ingah.daviscrawford@slu.edu. 


\author{
STRANGE TRAFFIC: \\ SEX, SLAVERY \& THE FREEDOM PRINCIPLE
}

ANDERS WALKER •

\begin{abstract}
This article uses the recent prosecution of a sex trafficking case in rural Missouri to argue three points. One, the federal law of trafficking is currently being used in unanticipated ways, including the apprehension of individuals involved in sadomasochistic relationships, a move that confirms recent studies questioning prosecutorial motivations for invoking the crime of trafficking. Two, trafficking invites creative use precisely because it provides prosecutors with a more compelling justification for punishment than either legal moralism or harm; a plea to the abolition of slavery, or what John Stuart Mill termed the "principle of freedom." Three, recovering the manner in which Mill's freedom principle operates in the trafficking context invites us to re-historicize the use of legal rhetoric in criminal law, demonstrating how reformers have consistently enlisted the rhetoric of freedom in the curtailment of rights.
\end{abstract}

\title{
TABLE OF CONTENTS
}

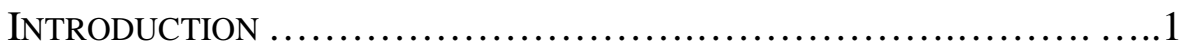

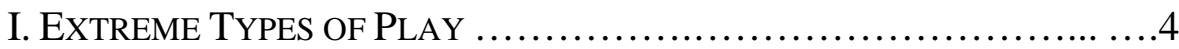

II. THE FREEDOM PRINCIPLE ......................................... 12

III. SEX WAR REDUX .............................................. 18

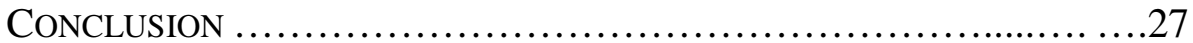

- Associate Professor, Saint Louis University School of Law; PhD Yale University 2003, JD Duke University 1998, BA Wesleyan University 1994. I would like to thank private attorney Susan L. Dill for sharing her insights into the Bagley case. I would also like to thank Bernadette Meyler, Annelise Riles, Josh Chafetz, Aziz Rana, and the Law \& Humanities Colloquium at Cornell Law School for comments \& criticism, as well as Laura Appleman, Norman Williams, David Friedman, Peter Letsou, and the faculty workshop series at Willamette Law School for comments on this piece, as well as Sam Jordan, Molly Walker Wilson, Marcia McCormick, and the faculty workshop series at Saint Louis University School of Law. Credit goes to Nicholas Burkhart for research assistance. 


\author{
STRANGE TRAFFIC: \\ SEX, SLAVERY \& THE FREEDOM PRINCIPLE
}

\author{
ANDERS WALKER
}

\title{
INTRODUCTION
}

On February 27, 2009, paramedics in Lebanon, Missouri responded to a call from an isolated trailer on a wooded hill, arriving to find a middle-aged man named Ed Bagley administering CPR to a petite, twenty-four year old woman. ${ }^{1}$ According to Bagley, the woman - who he referred to simply as Nicole - had collapsed on the floor of their trailer just prior to leaving for work. ${ }^{2}$ According to Nicole, who was later revived in a Springfield hospital, Bagley had alternately shocked and suffocated her in a fit of violent abuse, causing her to suffer cardiac arrest. $^{3}$ The near-death experience, Nicole later told federal authorities, marked the culmination of a brutal relationship involving torture, terror, and confinement. ${ }^{4}$

Aghast, federal prosecutor Cynthia Cordes ordered agents to the trailer, where they discovered a "dungeon" filled with cameras, ropes, and torture devices. ${ }^{5}$ Upon further questioning, Nicole revealed that Bagley had lured her into the trailer in 2002 with promises of a "great life,"

- Associate Professor, Saint Louis University School of Law; PhD Yale University 2003, JD Duke University 1998, BA Wesleyan University 1994. I would like to thank private attorney Susan L. Dill for sharing her insights into the Bagley case. I would also like to thank Bernadette Meyler, Annelise Riles, Josh Chafetz, Aziz Rana, and the Law \& Humanities Colloquium at Cornell Law School for comments \& criticism, as well as Laura Appleman, Norman Williams, David Friedman, Peter Letsou, and the faculty workshop series at Willamette Law School for comments on this piece, as well as Molly Walker Wilson, Marcia McCormick, and the Center for the Interdisciplinary Study of Law at Saint Louis University School of Law.

${ }^{1}$ Todd C. Frankel, A Missouri Town's Doubts About a Sex Torture Case, ST. LouIS Post-Dispatch, Nov. 5, 2010.

${ }^{2}$ Nicole's last name was never revealed. Instead, the government referred to her simply as Female Victim, or "FV" in its indictment. Superseding Indictment at 8, U.S. v. Bagley, et al., No. 10-00244-01/02/04/06-CR-W-DW (W.D.MO. 2011).

${ }^{3}$ Todd C. Frankel, A Missouri Town's Doubts About a Sex Torture Case, ST. LouIS Post-Dispatch, Nov. 5, 2010.

${ }^{4}$ Todd C. Frankel, A Missouri Town's Doubts About a Sex Torture Case, ST. LouIS Post-Dispatch, Nov. 5, 2010.

${ }^{5}$ Todd C. Frankel, A Missouri Town's Doubts About a Sex Torture Case, ST. LouIS Post-Dispatch, Nov. 5, 2010. 
meanwhile subjecting her to a pattern of sadistic violence that spanned almost seven years and took the couple from Missouri to Los Angeles for a pornographic photo shoot later sold to Taboo magazine. ${ }^{6}$ Convinced that she had stumbled across a case of modern slavery, Cordes charged Bagley with coercing Nicole into performing commercial sex acts, or trafficking, focusing on money that Ed received from individuals in Missouri to pay for the 2007 California trip.

That Nicole might have acquiesced to visiting California surfaced in 2010, when the St. Louis Post-Dispatch sent a reporter to Lebanon to investigate the case. ${ }^{7}$ Baffled by Bagley's arrest, locals claimed that Nicole boasted publicly of their sexual exploits, all part of a consensual "S \& M lifestyle" that she and Ed videotaped and posted on the internet. ${ }^{8}$ One co-worker even claimed that Nicole considered her trip to California a "blast," a story corroborated by California-based photographer Ken Marcus who had invited Ed and Nicole to Los Angeles in 2007 for the supposedly criminal photo shoot. ${ }^{9}$ To Marcus, who became aware of the couple by viewing one of their "live shows" online, the couple seemed happy, Ed seemed doting, and Nicole appeared excited to be on the West Coast. ${ }^{10}$ That Ed had coerced Nicole to go on the trip struck Marcus as implausible, particularly since Nicole expressed an interest in returning an interest she herself corroborated in an interview with Taboo in August 2007..$^{11}$

Nicole's apparent willingness to visit California raises questions about Bagley's trafficking charge, which spans a dramatic period of time from 2002 to 2009. Despite a high level of popular interest in the problem of trafficking, scholars have recently begun to question the extent to which alleged trafficking victims are actually coerced into sex. ${ }^{12}$ According to sociologists Ric Curtis and Karen Terry, many of the individuals suspected of being trafficked in America are actually free agents, individuals who engage willingly in prostitution to earn money. ${ }^{13}$ Yet, the

\footnotetext{
6 Todd C. Frankel, A Missouri Town's Doubts About a Sex Torture Case, ST. LOUIS Post-DispatCH, Nov. 5, 2010.

${ }^{7}$ Todd C. Frankel, A Missouri Town's Doubts About a Sex Torture Case, ST. LoUIS Post-Dispatch, Nov. 5, 2010.

8 Todd C. Frankel, A Missouri Town's Doubts About a Sex Torture Case, ST. LOUIS Post-DispatCH, Nov. 5, 2010.

9 Todd C. Frankel, A Missouri Town's Doubts About a Sex Torture Case, ST. LOUIS Post-DispatCH, Nov. 5, 2010.

${ }^{10}$ Hunter Walker, FBI Questions Hustler Editor, Photographer in Sex Slave Case, www.thewrap.com Sept. 12, 2010.

${ }^{11}$ Ernest Greene, Master Ed and slave nicole: Heartland Kink, 10 HUSTLER's TABOO 53 (2007).

${ }^{12}$ Kristen Hinman, Lost Boys: New Research Demolishes the Stereotype of the Underage Sex Worker - and Sparks an Outbreak of Denial Among Child-Sex-Trafficking Alarmists Nationwide, VillaGe VOICE, Nov. 2, 2011.

${ }^{13}$ RiC CURTIS, KAREN TERry, MEREDITH DANK, KiRK DOMBROWSKI, AND BILAL KHAN, The COMMERCial SEXUAl EXPloitATION OF CHILDREN In NEW YORK City, Volume One: The CSEC Population In New York City: Size, Characteristics, AND NeEdS (2008).
} 
motif of trafficking remains popular, argue Curtis and Terry, precisely because reformers find it a useful frame for advancing a variety of ulterior agendas. ${ }^{14}$

One such agenda is the protection of illegal immigrants. ${ }^{15}$ Already, academics have begun to show how reclassifying undocumented immigrants as victims of trafficking enables them to stay in the United States and avoid deportation. ${ }^{16}$ Scholars have also begun to show how the frame of trafficking can be an effective device for combating prostitution, adopted by liberal feminists and conservative evangelicals alike. ${ }^{17}$ Finally, trafficking has proven a remarkably effective cover for the expansion of prosecutorial power. Already, the U.S. Attorney's Office for the Western District of Missouri has drawn considerable federal funds by making itself one of the foremost hubs of human trafficking prosecutions in the United States, even though it lies far from any international border or port. ${ }^{18}$

While prosecutorial ambition, counter-prostitution, and immigrant protection all help to explain current interest in trafficking, Bagley's case carries with it implications that are even farther reaching, both for the law of trafficking and for the legal rhetoric of criminal law generally. To illustrate, this Article will proceed in three parts. Part I will review the facts in the Bagley indictment, underscoring the weak links in the prosecution's trafficking charge, meanwhile demonstrating how those weaknesses tell us something new about the scope and direction of trafficking prosecutions. Part II will place Bagley's prosecution within the larger context of legal rhetoric, showing how the cultural frame of trafficking points to a new justification for the criminal sanction - antislavery - that fits nicely in a post-harm, post legal moralist landscape; one that can be reconciled with an under-theorized version of what John Stuart Mill termed the "principle of freedom.” Part III will explore the broader historical implications of rethinking Mill in terms of a freedom principle rather than a harm principle, demonstrating the manner in which the

\footnotetext{
${ }^{14}$ Kristen Hinman, Lost Boys: New Research Demolishes the Stereotype of the Underage Sex Worker - and Sparks an Outbreak of Denial Among Child-Sex-Trafficking Alarmists Nationwide, Village VoicE, Nov. 2, 2011.

${ }^{15}$ Nicholas Kristof, What About American Girls Sold on the Streets?, N.Y. TIMES, Apr. 23, 2011.

${ }^{16}$ Britta S. Loftus, Coordinating U.S. Law on Immigration and Human Trafficking: Lifting the Lamp to Victims, 43 COLUM. HuM. RTS. L. REV. 143-44 (2011).

17 Janie A. Chuang, Rescuing Trafficking from Ideological Capture: Prostitution Reform and Anti-Trafficking Law and Policy, 158 U. PA. L. REV. 1655 (2010). Some have shown how trafficking has been used to aid teenage prostitutes who, once reclassified as trafficking victims, avoid criminal penalties and receive services Nicholas Kristof, What About American Girls Sold on the Streets?, N.Y. TIMES, Apr. 23, 2011.

${ }^{18}$ AC Team Announced for Kansas City, ThE VoICE FOR THE SEXUALLY EXPLOITED: THE OFFICIAL BLOG OF VERONICA’s VOICE, http://veronicasvoice inc.wordpress.com/tag/Cynthia-cordes/ (noting that Cynthia Cordes, Assistant U.S. Attorney and Human Trafficking Coordinator has been successful at creatively using the Trafficking Victims Protection Act to prosecute offenders).
} 
rhetoric of anti-slavery has consistently justified the curtailment of rights in the United States.

Once heralded as a legitimate source of moral regulation, criminal law became increasingly divorced from legal moralism over the course of the Twentieth Century, leading scholars like Bernard Harcourt to proclaim the formal death of legal moralism in 1999. ${ }^{19}$ Yet, just as Harcourt reported the internment of moralism, so too did he find its ghost stalking current invocations of legal harm. ${ }^{20}$ This Article agrees with that theory but adds to it, positing that in cases where the rhetoric of harm itself fails, prosecutors have begun to invoke a very different principle, one that was also advanced by J.S. Mill, rooted in liberty. ${ }^{21}$ In a manner that has been largely forgotten, Mill's freedom principle helps to explain a lost tradition in criminal law theory, one that not only animates current uses of the law of trafficking, but dates at least as far back as the passage of the White Slave Traffic Act, or Mann Act, in 1910. ${ }^{22}$

\section{I. "EXTREME TyPeS OF PLAY"}

If ever a federal indictment read like the script for a horror film, it is Ed Bagley's. Issued by a grand jury on March 29, 2011, the document claimed that Ed and his wife Marilyn lured Nicole, referred to simply as Female Victim, or "FV" into their trailer with promises of "a great life," including but not limited to, making her a "model," a "dancer," and making her "dreams come true." ${ }^{23}$ The Bagleys allegedly provided FV with a "bedroom, dresser, and television," along "with clothes and food," all in an effort "to entice her to stay in their trailer home." "From 2002 to 2004, the Bagleys "modeled 'slave clothes,"” and used "the internet and adult BDSM [bondage, dominance/discipline, submission/sadism, and masochism] pornography to train and groom FV to become a sex slave."25

\footnotetext{
${ }^{19}$ Bernard E. Harcourt, The Collapse of the Harm Principle, 90 JoURnAL OF CRIMINAL LAW \& CRIMINOLOGY 109 (1999); John Lawrence Hill, The Constitutional Status of Morals Legislation, 98 KY. L.J. 1, 14 (2009); Dan M. Kahan, The Cognitively Illiberal State, 60 StAN. L. REV. 115. 132 (2007); H.L.A. HART, LAW, LiBERTY, MORALITY (1963). But see Alice Ristroph, Third Wave Legal Moralism, 42 ARIZ. ST. L.J. 1151.

${ }^{20}$ Bernard E. Harcourt, The Collapse of the Harm Principle, 90 JoURNAL OF CRIMINAL LAW \& CRIMINOLOGY 109 (1999).

${ }^{21}$ Russell Hittinger, The Hart-Devlin Debate Revisited, 35 AM. J. JuRIs. 52 (1990) citing JOHN STUART MILL, ON LIBERTY 9 (Hackett, ed. 1978).

${ }^{22}$ See infra §II.

${ }^{23}$ Superseding Indictment at 8, U.S. v. Bagley, et al., No. 10-00244-01/02/04/06-CR-WDW (W.D.MO. 2011).

${ }^{24}$ Superseding Indictment, U.S. v. Bagley, et al., 8.

${ }^{25}$ Superseding Indictment, U.S. v. Bagley, et al., 8. For the legal definition of BDSM, see United States v. Marcus, 487 F. Supp. 2d. 289, 292 (2007).
} 
Ed Bagley also allegedly "had sexual intercourse with FV while she was still a minor.",26

Though Ed claims that Nicole was eighteen when they met, the indictment indicates she was younger. Whether she revealed her true age to Ed or not, Nicole appears to have first come into contact with him in December 2002, just prior to her seventeenth birthday. Then, “[i]n or about February 2003" when Nicole turned seventeen, she moved into Bagley's trailer - an arguably significant moment given that Missouri's age of consent is seventeen. ${ }^{27}$ That Bagley had intercourse with FV while she was still sixteen is entirely possible, but the indictment makes clear that he waited until Nicole turned eighteen to begin the activities that the federal government alleges were the basis of his trafficking charges. For example, the indictment alleges that “[s]hortly after" FV's $18^{\text {th }}$ birthday “on or about February 10, 2004," Ed Bagley had her “sign a 'sex slavery contract" and "instructed" her "that the contract legally bound her to him as his 'sex slave,' with a term that 'never' ended." ${ }^{28}$ Over the course of the following year, Bagley "had FV tattooed to mark her as his property," including "a bar code on FV's neck."29

Neither the bar code tattoo nor the slave contract were Bagley's creation, both having a larger currency in Dominant/submissive, or " $\mathrm{D} / \mathrm{s}$ " subculture. For example, the notion of a slave contract first emerged in an 1870 book by a German author named Leopold Von Sacher Masoch who used the contract to underscore a larger point about the relationship between intimacy and law, arguing that true intimacy need not be rooted in notions of equality, and that liberal preoccupations with equality actually obviate the possibility of achieving "the most intense human passion," the highest form of love, the giving of oneself completely to another. ${ }^{30}$ To Sacher Masoch, in other words, the slave contract represented a legitimate, superior alternative to both the marriage contract and to Locke's social contract, nothing less than the foundation for "a new social polity." 31

${ }^{26}$ Superseding Indictment, U.S. v. Bagley, et al., 8.
${ }^{27}$ Superseding Indictment, U.S. v. Bagley, et al., 8.
${ }^{28}$ Superseding Indictment, U.S. v. Bagley, et al., 9.
${ }^{29}$ Superseding Indictment, U.S. v. Bagley, et al., 9.
${ }^{30}$ LEOPOLD VON SACHER MASOCH, VENUS IN FURS (1870, New York: Penguin, 2000).

Nancy Bentley, The Strange Career of Love and Slavery: Chesnutt, Engels, Masoch 17.3 AMERICAN LITERARY HISTORY 475-76 2005).

31 Though Sacher Masoch's name would go on to inspire the term masochism, little evidence exists to indicate that either Ed Bagley or "slave nicole," as he referred to her on D/s blogs and in Taboo magazine, were aware of Venus in Furs. Yet, the text underscores the point that Bagley and Nicole's relationship may in fact have been consensual, their contract an effort to consecrate an intimate bond outside the confines of companionate marriage. Indeed, if Bentley's read of Sacher Masoch is correct, then the slave contract may - for some - be even more "intimate" than the marriage contract. Further, Nicole signed the contract when she was 18, the age at which she became a consenting adult, not just in the eyes of Missouri but the federal government as well. Nancy Bentley, The Strange Career of Love and Slavery: Chesnutt, Engels, Masoch 17.3 
As for the bar code tattoo, many attribute its origin to Canadian artist Jana Sterback, who used it to critique mass culture in a 1989 photograph of a prisoner with a tattoo on the back of his neck. ${ }^{32}$ Entitled Generic Man, the photo sparked a trend in bar code tattoos in the United States and abroad - with celebrities like popular entertainers Pink and Aubrie O'Day both acquiring them. ${ }^{33}$ In D/s culture, however, the tattoo assumed a more sinister significance; thanks in part to a novel by science fiction writer S.M. Stirling entitled The Domination. ${ }^{34}$ An alternate history, the book tells the story of a rogue group of American colonists who remain loyal to the British following the American Revolution, reject the new republic, and move their plantations and slaves to Africa. ${ }^{35}$ Once there, they found a fictional colony called Drakia, which tolerates slavery through the Twentieth Century, ultimately becoming a major imperial power opposed to the United States. ${ }^{36}$ In the book, slaves are acquired through conquest and given barcode numbers as part of a larger process of being "groomed" into lives of service that do not have anything to do with role-play. ${ }^{37}$ The book inspired the creation of the Master/slave Registry, an online service formed in 2000 that enables Masters to register their slaves by number. ${ }^{38}$

While The Domination suggests that the true purpose of Master/slave relationships is to recreate a non-racialized form of chattel slavery in the United States, proponents of the D/s lifestyle tend to assert

AMERICAN LITERARY HISTORY 475 ( 2005). A tangential question - not addressed by the U.S. Attorney or, arguably, the Trafficking Victims Protection Act - is whether the creation of a slave contract per se violates the $13^{\text {th }}$ Amendment. As President Barack Obama stated in a presidential proclamation on January 4, 2010, "President Abraham Lincoln issued the Emancipation Proclamation" not simply to end black slavery, but to consecrate the "essential principles" of "equality and freedom," throughout the nation, a nation where - in the $21^{\text {st }}$ Century - "the victims of modern slavery have many faces." Hence, perhaps even those who enter willingly into master/slave relationships violate the constitution by effectively seceding from the Union. Imagine, for example, if adherents to the S\&M master/slave lifestyle chose not simply to build communities on the internet, but to create actual, physical communities? Does the invisibility and/or nongeographicality of internet communities obscure what would otherwise be roundly condemned under the $13^{\text {th }}$ Amendment? See Barack Obama, Presidential Proclamation National Slavery and Human Trafficking Prevention Month, Jan. 4, 2010.

${ }^{32}$ Tanos, Slave Register Website History, www.slaveregister.com/about/history.

${ }^{33}$ In fact, one of her other pieces, the meat dress, also gained popular notoriety after it was donned by Stephanie Germanotta, aka Lady Gaga, at the 2010 MTV Video Music Awards. Here, we see a blurring of lines between popular culture, counter-culture, and D/s subculture - again explaining why a young person might be drawn into such a culture - attracted to its exotic/extreme nature more than its constitutional or criminal implications

${ }^{34}$ S.M. STIRLING, THE DOMINATION (1999).

${ }^{35}$ S.M. STIRLING, THE DOMINATION (1999).

36 S.M. STIRLING, THE DOMINATION (1999).

${ }^{37}$ S.M. STIRLING, THE DOMINATION (1999).

${ }^{38}$ S.M. STIRLING, THE DOMination (1999). For evidence of The Domination's impact on the Slave Register, see Tanos, Slave Register Website History,

www.slaveregister.com/about/history. 
that their relationships are more akin to role-play games, mutually consensual arrangements and therefore legal. ${ }^{39}$ This holds true even if money is exchanged, an instance that became widely publicized in D/s circles in 1996 when a twenty-two year old woman named Amanda posted a personal ad on alt.personals.bondage.com advertising herself for sale. ${ }^{40}$ According to Amanda, she was blonde, college-educated, and had been enjoying life "to its fullest" until she realized that her parents - who worked for "large acquisition corporations" - made their money by taking advantage of "less fortunate people," foreclosing on family-owned businesses to sell their "assets" and "make huge profits." 41 Claiming a desire to "atone for the sins of my family," Amanda offered herself for sale online to the highest bidder "as a sex slave" willing to "do and perform any perverse degrading and dehumanizing rituals” that her master may desire with the only requirement being that her owner "video tape one session a month to be sent to my parents so they know what my life has become." ${ }^{42}$ Two months later, the winner of Amanda's auction identified simply as "Master Mark," posted a message to the same blog, noting that "placing a monetary value to a slave exchange ensures that the submissive receives the best chance of being secured by a dominant who will appreciate, respect, and develop the slave's gift of submission."43 Here, the transfer of money not only added value to the Master/slave experience, but guaranteed some base level treatment of the slave, even though the slave herself authorized the performance of "perverse degrading and dehumanizing rituals” upon her. ${ }^{44}$

While Master Ed did not pay money for slave nicole, he did allegedly accept money from other men for purposes related to Nicole. For example, he took “approximately $\$ 1,400$ ” on one occasion, and “an

\footnotetext{
${ }^{39}$ This raises the question whether consensual slavery violates the Thirteenth Amendment. International law holds that slavery occurs whenever one party enjoys "the exercise of any or all powers attached to the right of ownership" over another. 1926 Convention on Slavery. "Equally," notes Mohamad Mattar, "practices similar to slavery ... such as debt bondage, serfdom, forced marriage, and sale of children are to be considered slavery-like conditions only if they involve "the status or condition of a person over whom any or all of the powers attaching the right of ownership are exercised.” Mohamed Y. Mattar, Interpreting Judicial Interpretations of the Criminal Statutes of the Trafficking Victims Protection Act: Ten Years Later, 19 AM. U. J. GENDER SOC. POL'Y \& L. 1247, 1258 (2011). Arguably more inclusive is the $13^{\text {th }}$ Amendment, which according to the $2^{\text {nd }}$ Circuit's decision United States $v$. Nelson is "the denunciation of a condition, and not a declaration in favor of a particular people" and, as the Ninth Circuit put it in United States v. Mussry, applies "to a variety of circumstances and conditions ... [and] to contemporary as well as historic forms of involuntary servitude.” Mohamed Y. Mattar, Interpreting Judicial Interpretations of the Criminal Statutes of the Trafficking Victims Protection Act: Ten Years Later, 19 AM. U. J. GENDER SOC. POL'Y \& L. 1247, 1260 (2011).

${ }^{40}$ Young Female Slave for Sale, alt.personals.bondage, Dec. 12, 1996.

${ }^{41}$ Young Female Slave for Sale, alt.personals.bondage, Dec. 12, 1996.

${ }^{42}$ Young Female Slave for Sale, alt.personals.bondage, Dec. 12, 1996.

${ }^{43}$ Comments on "Slaves Selling Themselves," alt.personals.bondage, Feb. 8, 1997.

${ }^{44}$ Young Female Slave for Sale, alt.personals.bondage, Dec. 12, 1996.
} 
additional \$500” on another from an individual named Dennis Henry for the "transportation" of Nicole to California to do a photo shoot for Taboo magazine. ${ }^{45}$ Bagley also allegedly accepted " $\$ 1,000$ " from another male named Michael Stokes "to transport FV to California." Finally, he took money from men interested in "watch[ing] and engage[ing] in" various alleged "torture activities" with Nicole. ${ }^{46}$

The exchange of money and other items, particularly for purposes of the California trip, played a critical role in the government's case against Bagley. To be convicted of trafficking, the federal government need not prove that the victim was transported, only that the defendant affected interstate commerce or benefited financially by causing the victim to "engage in a commercial sex act" either knowing that "force, threats of force, fraud, or coercion" were necessary to do so, or being "in reckless disregard of the fact." ${ }^{\prime 7}$ According to the statute, a commercial sex act comprises "any sex act on account of which anything of value is given or received by any person." 48 Meanwhile, coercion requires "threats of serious harm," "physical restraint," or any type of scheme or plan "intended to cause a person to believe" that if they did not perform an act then they would be subjected to "serious harm" or "physical restraint." 49

On the issue of coercion, Bagley had a unique defense in that Nicole consented publicly to much of his conduct, including her California trip. To illustrate, the government alleged that Bagley "tied FV's limbs behind her body and left her hanging, suspended in the air, or on a bench for long period's of time," "locked, chained and hooded FV naked in a dog cage, often suspending the cage in the air or attaching FV's sex organs to electrical devices while she was trapped in the cage," performed "waterboarding on FV," and conducted other violent acts, including "flogging, whipping, shocking, choking, piercing, skewering, sewing, stapling, and electrocuting" her. ${ }^{50}$

Though alarming to the outsider, the above behaviors were all endorsed by Nicole herself in an interview conducted by Taboo editor Ernest Greene in 2007, after she returned from California with Ed. ${ }^{51}$ Noting that the couple had come to the magazine's attention thanks to photographer Ken Marcus, Greene proceeded to inquire into the details of their relationship, including how they met. ${ }^{52}$ According to Nicole, she “didn't know anything about BDSM" before meeting Bagley, but thought he was "good-looking and seemed kind of on the wild side." ${ }^{33}$ Bagley, by contrast, remembered meeting Nicole through some friends, commenting

\footnotetext{
${ }^{45}$ Superseding Indictment, U.S. v. Bagley, et al.,15.

${ }^{46}$ Superseding Indictment, U.S. v. Bagley, et al., 19.

${ }^{47} 18$ U.S.C. 1591(a).

${ }^{48} 18$ U.S.C. $1591, \S 103$.

4918 U.S.C. $1591, \S 103$.

${ }^{50}$ Superseding Indictment, U.S. v. Bagley, et al., 7.

${ }^{51}$ Ernest Greene, Master Ed and slave nicole: Heartland Kink, 10 TAвоO 53 (2007).

${ }^{52}$ Ernest Greene, Master Ed and slave nicole: Heartland Kink, 10 TABOO 53 (2007).

${ }^{53}$ Ernest Greene, Master Ed and slave nicole: Heartland Kink, 10 TABOO 53 (2007).
} 
on how she "bounced out of the car, wearing shorts and a skimpy little top," immediately convincing him that "she was the slave girl for me." 54 Shortly thereafter, Nicole moved in with the Bagleys and, as she told Taboo, fell "in love with" Ed and Marilyn and decided to "stay[] with them and $\operatorname{lov}[\mathrm{e}]$ them for the rest of my life." 55 Rather than portray herself as a victim, in other words, Nicole described her relationship with Ed and Marilyn as a voluntary arrangement, on par with a marital relationship or possibly a familial relationship - a haunting affirmation of Leopold von Sacher Masoch's theory that slavery could in fact coincide with love.

Ed provided further insight into the dynamics of their D/s "play" sessions during their Taboo interview. Rather than aimed at hurting Nicole, Ed explained to Taboo that their activities resembled an evolving series of staged adventures, each one more radical than the last, in part to keep Nicole interested. For example, he explained that he "had to learn a lot" in order to "keep things fresh" with Nicole, including new "extreme types of play" like "catheter insertion, chastity sewing," and "nailing [Nicole] to a board," all activities later listed in the criminal indictment against him. ${ }^{56}$ Nicole spoke articulately about these actions and others, including "hanging upside down," "being hog-tied" and wearing "hoods for the suspense of wondering which whip or what toy i'll get next," including "gags to bite down when i feel the need to cry or scream." 57 Though some degree of discomfort or pain seemed to be involved in almost every action they described, Nicole also confessed that she had a "safe word," but did not like using it "unless i have to." 58

One way to explain Nicole's interview with Taboo is that she enjoyed their sessions, loved Ed, and was not trafficked to California. Another possible explanation is that Bagley somehow coerced her into saying the things she did. For example, Nicole might genuinely have been afraid that Bagley would hurt her if she did not pretend to condone their relationship in the Taboo interview, deciding instead to mask her fear in statements of enthusiasm. Of course, this begs the larger question why, over the course of the seven years that Nicole lived with Bagley, did she not try to escape, either by alerting neighbors, or physically absconding and contacting police? Such questions lend themselves either to Bagley's innocence or to the possibility that just like many victims of domestic violence, Nicole developed what Dee Graham and Del Martin have called "traumatic bonding," a condition where victims of domestic abuse develop an inability to leave or resist. ${ }^{59}$ Yet, the state refused to even engage the

\footnotetext{
${ }^{54}$ Ernest Greene, Master Ed and slave nicole: Heartland Kink, 10 TABOO 53 (2007).

${ }^{55}$ Ernest Greene, Master Ed and slave nicole: Heartland Kink, 10 TABOO 53 (2007).

${ }^{56}$ Ernest Greene, Master Ed and slave nicole: Heartland Kink, 10 TABOO 53 (2007).

${ }^{57}$ Ernest Greene, Master Ed and slave nicole: Heartland Kink, 10 TABOO 53 (2007).

${ }^{58}$ Ernest Greene, Master Ed and slave nicole: Heartland Kink, 10 TABOO 53 (2007).

${ }^{59}$ Dee L. Graham, et al, Survivors of Terror: Battered Women, Hostages, and the Stockholm Syndrome in Kersi Yllo \& Michelle Bograd, eds. FEMINIST PERSPECTIVES ON Wife Abuse 217-233 (1988); Del Martin, BATTEREd Wives (1976); Alfred DeMaris
} 
issue, focusing instead on proving that Bagley was a "sadist" and a "psychopath," neither of which were particularly relevant to the charge of trafficking. ${ }^{60}$ Even if Bagley was a psychopath, for example, Nicole could not be counted a victim of trafficking if she consented to their trips, "live shows," and "play" sessions, no matter how shocking they may have been to the uninitiated observer. ${ }^{61}$

Incidentally, even uninitiated observers refused to believe that Ed had trafficked Nicole. For example, witnesses in Lebanon who knew the couple bolstered Ed's claim that Nicole consented to all aspects of their $\mathrm{D} / \mathrm{s}$ relationship. For example, Lebanon local Lori Bredvick, a waitress at a local restaurant, explained to the St. Louis Post-Dispatch that Ed and Nicole frequented her restaurant often and "would always sit at a table in the back corner."62 Ed, according to Lorrie, was a quiet man," while the young woman was "very talkative and outgoing” and "openly talked about their sexual relationship."63 According to Bredvick, "they no more held that woman captive than a man on the moon," a story corroborated by others in the area, including Kelly Myers, a 25 year old dancer who worked with Nicole at the After Dark Gentlemen's Club near Fort Leonard Wood. According to Myers, stripping was Nicole’s “passion” and she took it very "seriously."64 Myers also claimed that Nicole had not been taken to California against her will, but rather that she "said she had a blast," raved about "how nice California is" and encouraged Myers "to go out there." 65

Witnesses in California confirmed Myers's version of events. Among them was Ken Marcus, longtime photographer for Playboy and Penthouse who worked with Nicole in Los Angeles. ${ }^{66}$ Upon questioning, Marcus claimed that he had invited Ed and Nicole to Los Angeles after viewing one of their "live shows" on Alt.com, an adult entertainment website owned by Penthouse Media Group. ${ }^{67}$ Marcus then conducted a

and Steven Swinford, Female Victims of Spousal Violence: Factors Influencing their Level of Fearfulness, 45 FAMILY RELATIONS 98 (1996). In such situations, individuals in Nicole's position may develop a "learned helplessness" that leads them to view their attacker as "invincible" and themselves as incapable of "taking any action against him." Robert Geffner \& Mildred Daley Pagelow, Victims of Spouse Abuse in Robert T. Ammerman \& Michel Hersen, eds. TREATMENT OF FAMILY Violence 113-135 (1990).

${ }^{60}$ Anders Walker phone interview with Susan Dill, April 12, 2012.

${ }^{61}$ Hunter Walker, FBI Questions Hustler Editor, Photographer in Sex Slave Case, www.thewrap.com Sept. 12, 2010.

${ }^{62}$ Todd C. Frankel, A Missouri Town's Doubts About a Sex Torture Case, ST. LOUIS Post-Dispatch, Nov. 5, 2010.

${ }^{63}$ Todd C. Frankel, A Missouri Town's Doubts About a Sex Torture Case, ST. LOUIS Post-Dispatch, Nov. 5, 2010.

${ }^{64}$ Todd C. Frankel, A Missouri Town's Doubts About a Sex Torture Case, ST. LOUIS PosT-Dispatch, Nov. 5, 2010.

${ }^{65} \mathrm{Id}$.

${ }^{66}$ Hunter Walker, FBI Questions Hustler Editor, Photographer in Sex Slave Case, www.thewrap.com Sept. 12, 2010.

${ }^{67}$ Hunter Walker, FBI Questions Hustler Editor, Photographer in Sex Slave Case, www.thewrap.com Sept. 12, 2010. 
series of shoots with Nicole and Anastasia Price, a professional S\&M model "over a period of several days," selling some of the photographs to Taboo magazine - a Larry Flynt publication dedicated to BDSM pornography - and reserving others for view on his personal site. ${ }^{68}$ Marcus also conducted an interview with Ed and Nicole during which she confessed that she had not been to L.A. before but "hope[d]" to return. ${ }^{69}$ As Marcus explained it, Ed and Nicole "seemed to be quite a lovely couple," and Ed appeared to be "going out of his way to make sure she was as happy as possible." ${ }^{, 0}$ Shocked to hear that Bagley had been arrested for trafficking, Marcus asserted that he witnessed no signs that Nicole was "forced, coerced, or mentally disabled." " Instead, he claimed that she appeared "bright, intelligent and in control."72

While it is certainly possible that Marcus, Myers, and Bredvick all misread the nature of Ed and Nicole's relationship, Nicole herself endorsed that relationship during her 2007 Taboo interview, conducted shortly after their return from Los Angeles. That Nicole might have lied is possible, particularly if she suffered from traumatic bonding. However, the government provided no evidence to that effect, making it appear unlikely that Nicole was coerced. Further, Ed Bagley himself seemed to think that Nicole went willingly; minimizing the likelihood that he either knowingly or recklessly coerced her, as required by the TVPA. For example, Bagley himself posted on Slavefarm.com that "slave nicole loved" the California experience and enjoyed "reading all the comments" online about the shoot. ${ }^{73}$ To his mind, the trip "made her want to try even

\footnotetext{
${ }^{68}$ Hunter Walker, FBI Questions Hustler Editor, Photographer in Sex Slave Case, www.thewrap.com Sept. 12, 2010.

${ }^{69}$ Hunter Walker, FBI Questions Hustler Editor, Photographer in Sex Slave Case, www.thewrap.com Sept. 12, 2010.

${ }^{70}$ Hunter Walker, FBI Questions Hustler Editor, Photographer in Sex Slave Case, www.thewrap.com Sept. 12, 2010.

${ }^{71}$ Hunter Walker, FBI Questions Hustler Editor, Photographer in Sex Slave Case, www.thewrap.com Sept. 12, 2010.

${ }^{72}$ Hunter Walker, FBI Questions Hustler Editor, Photographer in Sex Slave Case, www.thewrap.com, Sept. 12, 2010. Given that the government's Mann Act charge hinged on illegal activity in California - including allegations that Bagley coerced Nicole into the trip - Marcus's public statements cast Ed's alleged use of coercion into doubt, at least in relation to the California trip. For example, shortly after photographs from the shoot were published in Taboo, Bagley himself posted on Slavefarm.com that "slave nicole loved" the experience and enjoyed "reading all the comments" online about the shoot. To his mind, the trip "made her want to try even harder to be a good slave girl." Had Bagley known that he was facing a potential Mann Act charge, would he have blogged publicly about the trip? Or, conversely, was the act of blogging about the trip a deliberate effort to mask the fact that indeed, Nicole had been trafficked? Ken Marcus seemed to think no, as did Kelly Myers, the dancer in Fort Leonard Wood who told the Post-Dispatch that upon her return, Nicole claimed that her trip to California had been "a blast.” Master Ed, Hustler's Taboo Magazine, www.slavefarm.com, June 23, 2007; Todd C. Frankel, A Missouri Town's Doubts About a Sex Torture Case, ST. LOUIS PosTDisPATCH, Nov. 5, 2010.

${ }^{73}$ Master Ed, Hustler's Taboo Magazine, www.slavefarm.com, June 23, 2007.
} 
harder to be a good slave girl."74 Though this too might have been a subterfuge, the combined effect of his online comments, Nicole's tabloid interview, and eyewitness accounts in both Missouri and California all indicate that little evidence existed to support a trafficking charge. Why the government proceeded with the case, and what this means for the law of trafficking, is significant. As the next section shall demonstrate; the government's case against Ed Bagley points to a potentially new rhetorical frame for regulating private, consensual sex.

\section{THE FREEDOM PRINCIPLE}

Given the scant evidence of coercion underlying Bagley's Mann Act charge, together with the government's refusal to pursue a theory of traumatic bonding, trafficking appears a poor fit in Bagley's case. Yet, it is precisely this ill-fit that makes the case curious, raising the question whether there are ulterior regulatory motivations at work. For example, if Nicole had clearly been forced to commit commercial sex acts, either by suffering physical detention or threats of deportation, as befalls many undocumented sex workers, then the trafficking charge would warrant little comment. $^{75}$ Not so here. Nicole's consent to conduct central to the case, like the California trip, invites speculation as to prosecutorial intent.

One possible motivation behind the prosecution of Ed Bagley is moral disapprobation. Though most Americans are likely indifferent to the bedroom exploits of private couples, the extreme forms of "play" that Ed and Nicole participated in may strike some as morally problematic, particularly given Nicole's relatively young age when the relationship began. Evidence of this can be found in conservative responses to E.L. James's novel Fifty Shades of Grey, a best-selling romance published in 2012 that describes a relationship akin to the one shared by Ed and Nicole. $^{76}$ In the book, twenty-two year old protagonist Anastasia Steele is asked by an older man, Christian Grey, to enter into a written contract substantially restricting her freedom, including her ability to speak about their relationship as well as her conduct within the relationship - which involves BDSM "play.",77 Libraries in places as disparate as Maryland, Florida, Georgia and Wisconsin refused to carry the book, while evangelical critics voiced their opposition to moral themes in the work, calling it "contrary to what the Bible says," and "damaging to our view of sex and our relationship with God."78

\footnotetext{
${ }^{74}$ Master Ed, Hustler's Taboo Magazine, www.slavefarm.com, June 23, 2007.

75 See, e.g. The Slave NeXT DoOR: HumAN TrafFICKING AND SlaVERY IN AMERICA TODAY (Kevin Bales \& Ron Soodalter, eds., 2009).

${ }^{76}$ E.L. James Feels the Love from 'Gray' Fans, LOS ANGELES TIMES, July 14, 2012, 1 D.

${ }^{77}$ E.L. James, Fifty Shades of Grey (2011, New York: Vintage, 2012).

${ }^{78}$ SELENA SARNS, 50 SHADES Of BlaCK AND White: A BibliCAL RESPONSE TO 50 SHADES OF GREY (2012); 'Controversy over '50 Shades of Grey,' WASHINGTON POST, June 5, 2012, B02; Too Hot to Handle? TELEGRAPH HerAlD (Dubuque), June 3, 2012,
} 
Of course, if Bagley's prosecutors felt moral outrage at his behavior, they would have good reason to couch their anger in nonmoralist terms, like trafficking. For one, no federal law currently exists to prosecute fully-consenting $\mathrm{D} / \mathrm{s}$ practitioners simply for their conduct. Two, even if such a law were to exist, it would probably fail constitutional muster. $^{79}$ As late as 2003, the Supreme Court declared that the Constitution did not brook the regulation of consensual sexual behavior between adults simply for moral reasons, thereby delivering what legal theorist Bernard Harcourt has termed a "coup de grace to legal moralism." 80 The case, Lawrence v. Texas, invalidated a sodomy law that had been invoked against a same-sex couple in Houston, marking a dramatic deregulation of gay relationships, not to mention all manner of other relationships that local majorities might term illicit. ${ }^{81}$ To those morally-minded majorities, the Court sent a clear message, noting "the fact that the governing majority in a state has traditionally viewed a particular practice as immoral, is not a sufficient reason for upholding a law prohibiting the practice." ${ }^{2}$ This, the Court maintained, was particularly true in cases where the sexual behavior in question was practiced between consenting adults in the privacy of their own home. ${ }^{83}$

Though focused on homosexual relationships, Lawrence carried with it broader implications for those involved in other "illicit" behaviors as well, like BDSM. For example, many state sodomy laws included anal and oral sex between opposite-sex partners in their range of prohibited activities. ${ }^{84}$ Lawrence's declaration that such activities enjoyed protection under the liberty interest of the Fourteenth Amendment transported a considerable amount of historically illicit behavior across what legal historian Ariela Dubler has termed the “illicit/licit divide," making it impossible to regulate couples like Ed and Nicole on strictly moral grounds. ${ }^{85}$ While Dubler focuses on the relationship between the

46; Pastor Jay Dennis, Revival and 50 Shades of Grey www.churchattthemall.com; Kasey Harris, 50 Shades of Grey - Should We Read It? changingfaceofchristianity.com; Tied Up in Knots: '50 Shades' Making It Even Tougher for Evangelicals to Address the Touchy Topic of Sex," STATE JOURNAL-REGISTER (Springfield, IL), Dec. 8, 2012, 20.

${ }^{79}$ E.L. James is USA TODAY's Author of the Year, USA TODAY, Dec. 20, 2012, 1D.

${ }^{80}$ Bernard E. Harcourt, Foreword: "You are Entering a Gay and Lesbian Free Zone": On the Radical Dissents of Justice Scalia and Other (Post-) Queers. Raising Questions about Lawrence, Sex Wars, and the Criminal Law, 94 J. CRIM. L. \& CRIMINOLOGY 503 (2004). [Hereinafter Raising Questions about Lawrence, Sex Wars, and the Criminal Law].

${ }^{81}$ Ariela R. Dubler, Immoral Purposes: Marriage and the Genus of Illicit Sex, 115 YALE L. J. 759 (2006).

${ }^{82}$ Lawrence, 123 S.Ct at 2483 (quoting Bowers, 478 U.S. at 216 (Stevens, J., dissenting)).

${ }^{83}$ Ariela R. Dubler, Immoral Purposes: Marriage and the Genus of Illicit Sex, 115 YALE L. J. 759 (2006).

${ }^{84}$ The Supreme upheld one such law in 1986, over a decade before Lawrence. See Bowers v. Hardwick, 478 U.S. 186 (1986).

${ }^{85}$ Ariela R. Dubler, Immoral Purposes: Marriage and the Genus of Illicit Sex, 115 YALE L. J. 759 (2006). 
illicit/licit divide and marriage, highlighting the fact that the Supreme Court has yet to extend the right to marry to same-sex couples - her point underscores the larger fact that what is and is not illicit remains contested. While some, like the majority in Lawrence, seem to believe that the Constitution should protect gay sex but not gay marriage, others disagree; holding either that gay sex and gay marriage should both be sanctioned by the $14^{\text {th }}$ Amendment, or not. Justice Antonin Scalia articulated the latter view in his Lawrence dissent, framing the struggle over the illicit/licit divide in terms not of constitutional interpretation but cultural war. ${ }^{86}$ "It is clear from this [decision] that the Court has taken sides in the culture war," lamented Scalia, "departing from its role of assuring, as neutral observer, that the democratic rules of engagement are observed." ${ }^{87}$ Though unclear on how precisely the Court might remain a "neutral observer" in liberty interest cases, Scalia's dissent highlights the oftobscured fact that the illicit/licit divide is itself a political battle line; a contested front in what Bernard Harcourt has termed "a war of sexual projects that is being fought on American soil." 88

Ed and Nicole's place in those projects is worth contemplating, if for no other reason than to better discern why, precisely Ed was prosecuted. As we have already considered, his charge may stem from a deep moral aversion to the manner in which he treated Nicole. However, no law proscribes D/s relationships simply as a matter of morality, nor would such a law likely survive constitutional muster. Therefore, the government's "sexual project" may be to cloak legal moralism in the garb of trafficking, essentially invoking a new rubric for fighting a cultural war that extends far beyond simply sanctioning or circumscribing homosexuality.

Looked at from the standpoint of Bagley's prosecution, "sexual projects" can extend to all manner of regulatory agendas, better describing the issues at stake in America's cultural/legal battles over the illicit/licit divide than simply referencing a straight or "homosexual agenda" - or for that matter a liberal and conservative agenda. ${ }^{89}$ Instead, there might be many agendas, as Bernard Harcourt maintains, in part because "[s]exuality is so central to each individual that every person has a sexual project," or a "position on how others should act sexually." 90 Though Harcourt underscores the personal dimension to such projects, his analysis can be

\footnotetext{
${ }^{86}$ Lawrence, 123 S. Ct. at 2497 (Scalia, J., dissenting).

${ }^{87}$ Lawrence, 123 S. Ct. at 2497 (Scalia, J., dissenting).

${ }^{88}$ Bernard E. Harcourt, Foreword: "You are Entering a Gay and Lesbian Free Zone": On the Radical Dissents of Justice Scalia and Other (Post-) Queers. Raising Questions about Lawrence, Sex Wars, and the Criminal Law, 94 J. CRIM. L. \& CRIMINOLOGY 503, 506 (2004).

${ }^{89}$ Lawrence, 123 S. Ct. at 2497 (Scalia, J., dissenting).

${ }^{90}$ Bernard E. Harcourt, Foreword: "You are Entering a Gay and Lesbian Free Zone": On the Radical Dissents of Justice Scalia and Other (Post-) Queers. Raising Questions about Lawrence, Sex Wars, and the Criminal Law, 94 J. Crim. L. \& CRIMINOLOGY 503, 524 (2004).
} 
extended to incorporate larger constituencies, including groups interested in preserving class or race power. Historically, for example, the illicit/licit divide played a recurring role in the European colonial context as white colonial administrators worked to paint the sexual practices of indigenous peoples in illicit tones, thereby sanctioning colonial rule. ${ }^{91}$ A similar pattern emerged in the United States; not just in colonial contexts like the Philippines but also in Native American-white interactions in the West, and racial politics in the American South. ${ }^{92}$ Southern elites consistently associated Africans with sexually illicit behavior, thereby rationalizing slavery as a civilizing project; one that whites continued after the Civil War as they justified the disfranchisement and segregation of black populations precisely because they were prone to moral "degeneration."93 After Brown v. Board of Education, white elites persisted in these efforts by directing public attention to black illegitimacy rates, painting African Americans as sexually profligate, promiscuous, and undeserving of state aid. ${ }^{94}$ Not until the 1970 s did the Supreme Court disrupt such projects, deciding a string of southern cases barring discrimination based on illegitimate status. ${ }^{95}$

Contemporaneous with the Supreme Court's illegitimacy cases emerged a string of rulings in the 1960s and 70s that stemmed from a very different sexual project, not the regulation of African Americans but the deregulation of non-procreative, recreational sex. In 1965, for example, the Court handed married couples interested in non-procreative sex a major victory by declaring that the Fourteenth Amendment barred state bans on contraception. ${ }^{96}$ Two years later, the Court liberalized controls of sexually explicit literature, meanwhile allowing for the possession of pornography in the privacy of the home in $1969 .^{97}$ By the close of 1973, the Court extended its ruling against contraception bans to non-married couples, meanwhile striking down state bans on abortion. ${ }^{98}$

\footnotetext{
${ }^{91}$ ANN LAURA STOLER, RACE AND THE EDUCATION OF DESIRE: FouCAUlT's HistORY OF SEXUALITY AND THE COLONIAL ORDER OF THINGS (1995).

${ }^{92}$ ANN LAURA STOLER, HAUNTED BY EMPIRE: GEOGRAPHIES OF INTIMACY IN NORTH AMERICAN HISTORY (2006).

${ }^{93}$ WINTHROP JORDAN, WHITE OVER BLACK: AMERICAN ATTITUDES TOWARD THE Negro, 1550-1812 (1968); Joel Williamson, THE CRUCIBLE OF RACE: BLACK-WHite RELATIONS IN THE AMERICAN SOUTH SINCE EMANCIPATION (1984); C. VANN WoODWARD, THE STRANGE CAREER OF JiM CROW (1957, New York: Oxford University Press, 1974); GLENDA ELIZABETH GILMORE, GENDER \& JiM CROW: WOMEN AND THE Politics of White Supremacy in North CAROlinA, 1896-1920 (1996).

${ }^{94}$ Anders Walker, “A Horrible Fascination”: Segregation, Obscenity, and the Cultural Contingency of Rights, 89 WASHINGTON UNIVERSITY L. REV. 1017 (2012).

${ }^{95}$ Levy v. Louisiana, 391 U.S. 68 (1968); Glona v. American Guaranty, 391 U.S. 73 (1968); Anders Walker, “A Horrible Fascination”: Segregation, Obscenity, and the Cultural Contingency of Rights, 89 WASHINGTON UNIVERSITY L. REV. 1017 (2012).

${ }^{96}$ Griswold v. Connecticut, 381 U.S. 479 (1965).

${ }^{97}$ Redrup v. New York, 386 U.S. 767 (1967) (holding that written materials not sold to minors or unwilling audiences enjoyed constitutional protection); Stanley v. Georgia, 394 U.S. 557 (1969).

${ }^{98}$ Eisenstadt v. Baird, 405 U.S. 438 (1972), Roe v. Wade, 410 U.S. 113 (1973).
} 
As Bernard Harcourt has shown, the Supreme Court's rapid reversal of moral regulations in the 1960s and 70s coincided with a growing sense in criminal theory circles that only harmful behavior should warrant criminal punishment. An English committee charged with investigating homosexuality and prostitution arrived at this position in 1957, as did American reformers working on a model penal code for the American Law Institute in $1962 .{ }^{99}$ Both responded to a perceived threat that legal moralism encouraged over-criminalization, prompting liberal theorist H.L.A. Hart to resurrect J.S. Mill's harm principle in a 1963 book challenging deontological justifications for the criminal sanction. ${ }^{100}$ Specifically, Hart "pared” Mill's argument "down to its original, simple, and succinct statement," noting that "[t]he only purpose for which power can rightfully be exercised over any member of a civilized community against his will is to prevent harm to others."101 This move, Harcourt explains "structured the debate over the legal enforcement of morality" for the remainder of the twentieth century, pitting legal moralism against the harm principle. ${ }^{102}$

Just as Bagley's prosecution might be an effort to couch legal moralism in the rhetoric of trafficking, so too might it use trafficking to cloak a prosecutorial desire to prevent harm. Here too, however, Lawrence poses problems. For example, the Court in Lawrence ignored claims that sodomy threatened the spread of sexually transmitted diseases, holding instead that the Fourteenth Amendment protected private consensual behavior, whether it in fact caused harm or not. ${ }^{103}$ While it is certainly possible that the U.S. Attorney felt that Bagley harmed Nicole, in other words, Lawrence acts like a defensive bulwark in this particular sexual project, deterring efforts to invoke harm as a justification for regulating consensual BDSM practice.

Given the challenges posed by Lawrence to BDSM cases, it remains possible that trafficking provides a rhetorical way forward, a siege engine in the "war of sexual projects." 104 Yet, this too is curious. As a matter of law, trafficking hinges on proving the element of coercion, something that does not appear to be prominent, even existent, in Bagley's treatment of Nicole. So, why invoke the crime? One possibility is that trafficking presents rhetorical possibilities that other criminal penalties do

\footnotetext{
${ }^{99}$ Bernard E. Harcourt, The Collapse of the Harm Principle, 90 J. CRIM. L. \& CRIMINOLOGY 122 (1999).

${ }^{100}$ Bernard E. Harcourt, The Collapse of the Harm Principle, 90 J. CRIM. L. \& Criminology 122-123 (1999) citing Patrick Devlin, Morals and the Criminal Law, in THE ENFORCEMENT OF MORALS (1965).

${ }^{101}$ H.L.A. Hart, Law, Liberty, and Morality 4 (1963), citing JOHN STUART MILL, ON LIBERTY 9 (1859, Indianapolis: Hackett, 1978).

${ }^{102}$ Bernard E. Harcourt, The Collapse of the Harm Principle, 90 J. CRIM. L. \& CRIMINOLOGY 122-123 (1999).

${ }^{103}$ Brief for Liberty Counsel as Amicus Curiae Supporting Respondent, Lawrence v. Texas, 539 U.S. 558 (2003), 2003 WL 470088.

${ }^{104}$ Harcourt, Foreword, 506.
} 
not, possibilities that render it a powerful weapon against the Supreme Court's firewall surrounding intimate conduct in Lawrence. For example, even as Lawrence hinges on the arguably popular notion that the Constitution protects a liberty interest in private sexual conduct, trafficking bounds that conduct by requiring that it not involve holding others in bondage. Closely tied to the rhetoric of trafficking, in other words, is the rhetoric of slavery, a cultural frame that engenders considerable popular outrage, marshals considerable regulatory potential, and seems to fit nicely with Bagley's case. ${ }^{105}$

While Bagley can claim that Nicole engaged willingly in her own enslavement, jurors might find it repugnant that he asked her to sign a formal slave contract, a violation of a core principle more profound then either legal moralism or harm. Indeed, the idea that one might sign away one's liberty seems to defy the very purpose of the $14^{\text {th }}$ Amendment's liberty interest, an interest forged in the aftermath of a bloody civil war dedicated to eradicating human bondage. Further, the notion that one might surrender one's liberty also falls askance of the principles espoused by John Stuart Mill. According to Mill, allowing an individual to "sell himself, or allow himself to be sold, as a slave" violates the "principle of freedom."106 This principle, argued Mill, operates independent of people's desires, even their desires to avoid harm. Even if one found it "desirable" to be a slave, for example, perhaps because being a slave meant a more sexually exciting life, the state should not allow individuals to sacrifice their freedom even then, for doing so prevents them from taking advantage of "the very purpose" of that freedom in the first place, namely the development of "individuality." 107 "[I]t is only the development of individuality," argued Mill, "which produces, or can produce, well-developed human beings. ${ }^{108}$

Mills' interest in the development of individuality is worth noting, and comparing to his better known aversion to harm. While the invocation of harm lends itself to assaults on legal moralism and the decriminalization of previously proscribed activities, the celebration of individuality invites a more ambiguous regulatory agenda. In fact, one might say that the principle of freedom introduces a new rhetorical mode for justifying the criminal sanction, one that transcends both legal

105 The Slave NeXt DoOR: HuMAN TRAFFICKING AND SLAVERY IN AMERICA TODAY (Kevin Bales \& Ron Soodalter eds., 2009); For a discussion of cultural frames, see ELlEN ANN ANDERSEN, OUT OF THE ClOSETS \& INTO THE COURTS: LEGAL OpPORTUNITY STRUCTRE AND GAY RIGHTS LiTIGATION (2005); Mayer Zald, Culture, Ideology, and Strategic Framing in COMPARATIVE PERSPECTIVES ON SOCIAL MOVEMENTS: POLITICAL Opportunities, Moblizing STRUCTURES, AND Cultural Framings 261 (Doug McAdam, et al. eds., 1996); David A. Snow, et al., Frame Alignment Processes, Micromobilization, and Movement Participation, 51 AM. SocIOLOGICAL REV. 464 (1986).

106 JOHN STUART MiLL, ON LIBERTY 101 (1859, Indianapolis: Hackett, 1978).

107 JOHN STUART MILL, ON LIBERTY 60 (1859, Indianapolis: Hackett, 1978).

108 JOHN STUART MILL, ON LIBERTY 61 (1859, Indianapolis: Hackett, 1978). 
moralism and harm. For example, even though Hart and others associate the harm principle with Mill, their version of that principle is considerably "pared" down from the full theoretical apparatus that Mill describes in On Liberty. Most notably, Hart and company tend to occlude any mention of the development of "individuality" perhaps because it opens the door to new regulatory frontiers - frontiers that may or may not be "progressive" in nature.

To illustrate, Leopold von Sacher Masoch argues in Venus in Furs that slavery might actually be a fulfilling legal bond, an even purer expression of personal sacrifice and love than marriage. ${ }^{109}$ Assuming this to be true, such a position may not necessarily violate Mill's harm principle. Take Amanda, the slave who sold herself to punish her parents, as an example. Even though Amanda acquiesced to degrading rituals, she may actually have enjoyed better treatment, and less harm, as a slave than as a free individual burdened with the guilt of her parents' cruelty. Behind Sacher Masoch's pitch for slavery, in other words, may rest an apology for the harm principle but a rejection of Mill's interest in the "principle of freedom"110

\section{SEX WAR REDUX}

Rereading Mill to incorporate a "principle of freedom" enables us to recover a new rhetorical basis for the criminal sanction, even as it pushes us to re-historicize the deployment of legal rhetoric in the context of criminal law. For example, Bernard Harcourt argues that the ascendance of the harm principle became so pervasive by the year 2000 that it actually led to a collapse of the old harm/moralism dichotomy, yielding instead a "cacophony of competing harm arguments without any way to resolve them." 111 The end result of this, argues Harcourt, is that at some point “[a]nother structure will surely emerge," perhaps even increasing our "appreciation that there is harm in most human activities." 112

Bagley's case indicates that an alternate structure of criminal law rhetoric has in fact emerged, namely the legal rhetoric of anti-slavery, or what Mill termed the "principle of freedom." Pursuant to this theory,

\footnotetext{
${ }^{109}$ Nancy Bentley, The Strange Career of Love and Slavery: Chesnutt, Engels, Masoch 17.3 AMERICAN LITERARY HISTORY 475 (2005).

${ }^{110}$ This critique was carried forward by thinkers like Michel Foucault, who "praised sado-masochistic sexual practices for 'inventing new possibilites of pleasure' through the 'eroticization of power.'” James Miller, Carnivals of Atrocity: Foucault, Nietzsche, Cruelty, 18 Political THEORY 485 (1990), citing Michel Foucault, An Interview: Sex, Power, and the Politics of Identity, ADVOCATE, August 7, 1984, 27.

${ }^{111}$ Bernard E. Harcourt, Collapse of the Harm Principle, 90 J. CRIM. L. \& CRIMINOLOGY 115, 119 (1999).

${ }^{112}$ Bernard E. Harcourt, Collapse of the Harm Principle, 90 J. CRIM. L. \& CRIMINOLOGY 115, 120 (1999).
} 
Bagley warrants punishment not because he hurt Nicole; but because he took her freedom, making it impossible for her to develop her "individuality." "113 As his indictment states: Bagley "had" Nicole sign a "sex slavery contract' that "legally bound her to him" with a "term that 'never' ended."114

While the invocation of anti-slavery rhetoric against Bagley may appear to be a new move in the American sex wars, his indictment indicates otherwise. In addition to charging Bagley with trafficking, for example, Cynthia Cordes also charged him with violating the Mann Act (for taking Nicole to California). ${ }^{115}$ Born midst a moral panic over "white slavery" at the turn of the twentieth century, the Mann Act remains one of the single-most controversial pieces of legislation in American history. ${ }^{116}$ Historians generally agree that the stated reasons for the law, a fear that white women were being lured into sexual slavery, lacked substantial evidentiary basis. ${ }^{117}$ Instead, the legislation became a rhetorical method for advancing a host of ulterior agendas, including restricting immigration, regulating prostitution, preserving conservative social values, and targeting unpopular minorities. ${ }^{118}$ Precisely because it lent itself to such politicized uses, the Mann Act might be described as an early sanction invoking the rhetoric of slavery to criminalize "illicit" behaviors - in short an early version of the same sexual project that is being used to target Ed Bagley. ${ }^{119}$

While Harcourt is certainly correct that conservatives endorsed harm arguments in the 1990s, in other words, a brief look at the climate

113 JOHN StUART MiLL, ON LIBERTY 61 (1859, Indianapolis: Hackett, 1978).

${ }^{114}$ Superseding Indictment at 8, U.S. v. Bagley, et al., No. 10-00244-01/02/04/06-CR-WDW (W.D.MO. 2011).

${ }^{115}$ Superseding Indictment at 8, U.S. v. Bagley, et al., No. 10-00244-01/02/04/06-CR-WDW (W.D.MO. 2011).

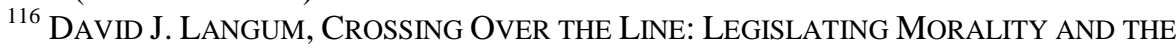
MANN ACT 1-5 (1994).

${ }^{117}$ DAVID J. LANGUM, CROSSING OVER THE Line: LEgISLATING MORALITY AND THE MANN ACT 6 (1994).

118 Ariela Dubler, Immoral Purposes: Marriage and the Genus of Illicit Sex, 115 YALE L. J. 756 (2006); Ethan A. Nadelmann, Global Prohibition Regimes: The Evolution of Norms in International Society, 44 INT’L ORG. 479, 513 (1990) (explaining the link between white slavery rhetoric and prostitution); Nicholas Kristof, What About American Girls Sold on the Streets?, N.Y. TIMES, Apr. 23, 2011; Britta S. Loftus, Coordinating U.S. Law on Immigration and Human Trafficking: Lifting the Lamp to Victims, 43 Colum. HuM. RTS. L. REV. 143-44 (2011).

${ }^{119}$ Mann Act prosecutions declined over the course of the Twentieth Century. Yet, the Act lived on, amended five times between 1948 and 1986. As currently written, the statute punishes individuals who transport others across state lines for illegal sex, in Bagley's case trafficking. However, trafficking itself requires coercion, an element that cannot be satisfied if the victim acquiesced to the sexual conduct in question.18 U.S.C. $\S 2421-2424$ (2006); Victims of Trafficking and Violence Protection Act of 2000, Pub. L. No. 106-386, 114 Stat. 1464 (2000). See generally DAVID J. LANGUM, CROSSING OvER THE Line: LEgislating MORALiTy AND THE MANN ACT 153 (1994). Victims of Trafficking and Violence Protection Act of 2000, Pub. L. No. 106-386, 114 Stat. 1464 (2000). 
that produced the Mann Act indicates the current cacophony in criminal law may not be entirely new. For example, reformers like Anthony Comstock began to enlist harm arguments in the regulation of illicit sex as early as 1872, not long after Mill finished On Liberty. ${ }^{120}$ According to historian Nicola Beisel, the "overwhelming majority" of Comstock's reasons for attacking pornography in the 1870s "concern[ed] its effects on children," including both its negative moral and physical effects. ${ }^{121}$ Among the physical effects that Comstock focused on was pornography's tendency to encourage the "fatal habit of masturbation," a physical and psychological “debility." 122

Driving Comstock's invocation of harm was a concern over lagging morals, particularly regarding pornography and prostitution, the latter of which was not only tolerated in most cities but legalized in some, including St. Louis in 1870. ${ }^{123}$ As historian Paul Boyer notes, St. Louis's decision to legalize prostitution set-off "alarm bells" in "moral reform circles all over the country." 124 However, such bells did not simply stir moral arguments; they also roused the rhetoric of harm. For example, nineteenth century reformers argued that prostitution threatened not simply moral decline but a syphilis epidemic as "debauched husbands" brought the disease home to their wives. ${ }^{125}$ Consternation over prostitution's role in spreading venereal disease to innocents spawned a "social hygiene movement" that then merged with a more moralist "Purity Movement" to suppress prostitution completely. ${ }^{126}$ As historian David Langum notes, cities across America suddenly "began to discover they had vice problems" and formed vice commissions to investigate segregated red light districts, ultimately leading to their abolition. ${ }^{127}$

Anti-vice crusades provide convincing evidence of how moral arguments and harm arguments merged in the $19^{\text {th }}$ Century, engendering a cacophony not entirely unlike that which Harcourt describes today. For example, historian Nicola Beisel notes that "[t]he anti-vice crusade[s]" of the nineteenth century "gained legitimacy from the claim that children

\footnotetext{
${ }^{120}$ NICOLA BEISEL, IMPERILED INNOCENTS: ANTHONY COMSTOCK AND FAMILY REPRODUCTION IN VICTORIAN AMERICA 86-7 (1997).

${ }^{121}$ NICOLA BEISEL, IMPERILED INNOCENTS: ANTHONY COMSTOCK AND FAMILY REPRODUCTION IN VICTORIAN AMERICA 86-7 (1997).

122 NICOLA BEISEL, IMPERILED INNOCENTS: ANTHONY COMSTOCK AND FAMILY REPRODUCTION IN VICTORIAN AMERICA 53-55 (1997).

${ }^{123}$ Paul Boyer, Urban Masses AND Moral Order IN AMERICA, 1820-1920, 143 (1978).

${ }^{124}$ PaUl Boyer, Urban Masses AND Moral Order In AMERICA, 1820-1920, 143

(1978).

125 NICOLA BEISEL, IMPERILED INNOCENTS: ANTHONY COMSTOCK AND FAMILY REPRODUCTION IN VICTORIAN AMERICA 22 (1997).

${ }^{126}$ DAVID LANGUM, Crossing OVER THE Line: LEGISLATING MORALiTY AND THE MANN ACT 22-23 (1994).

${ }^{127}$ DAVID LANGUM, Crossing Over the Line: Legislating MORALity AND THE MANN ACT 25 (1994).
} 
were threatened by the vices reformers sought to suppress.”128 These included prostitution, pornography, and extra-marital sex - a problem facilitated by the easy availability of contraceptives and abortion. ${ }^{129}$ Reformers like Anthony Comstock targeted such issues, pushing states to criminalize the transfer of obscenity in the mail, the distribution of contraceptives, and the performing of abortions - the latter of which "had been legal in virtually all of the states until the 1850s."130 Such issues, argues Beisel, including dangers of "pornography" and "the corruption of children by libidinous and pervasive popular culture" prefigured “contemporary political concerns.", 131

Animating the rise of harm arguments in the nineteenth century was a sense on the part of some reformers that morality alone did not sufficiently justify why certain behaviors needed to be controlled. For example, many proponents of the charity organization movement "rejected" the "church-related approaches" prevalent earlier in the nineteenth century, partly for fear that churches might opt not to root out vice so much as to use it as a shaming device for boosting church attendance. $^{132}$ Of particular concern in this regard was the Catholic Church, an institution popular among urban immigrants yet reviled by Protestant reformers who suspected it of tolerating vice as an ineradicable "sin" and therefore an "inevitable" part of life. ${ }^{133}$ Sectarianism, in other words, fueled the turn away from moral arguments and toward the harm principle.

Yet, harm arguments were themselves disputed at the close of the nineteenth century. For example, radical reformers like Victoria Woodhull and Tennessee Claflin both argued that behind Comstock's antivice crusade lay a more sinister campaign to subordinate women, partly by subjecting them to the male-dominated institution of marriage. ${ }^{134}$ Proponents of extra-marital sex, or "free love" as it was called at the time, joined Woodhull, Claflin, and other radicals like Ezra Heywood, who

\footnotetext{
${ }^{128}$ NICOLA BEISEL, IMPERILED INNOCENTS: ANTHONY COMSTOCK AND FAMILY REPRODUCTION IN VICTORIAN AMERICA 4 (1997).

${ }^{129}$ NICOLA BEISEL, IMPERILED INNOCENTS: ANTHONY COMSTOCK AND FAMILY REPRODUCTION IN VICTORIAN AMERICA (1997).

130 NICOLA BEISEL, IMPERILED INNOCENTS: ANTHONY COMSTOCK AND FAMILY REPRODUCTION IN VICTORIAN AMERICA 25 (1997).

${ }^{131}$ NICOLA BEISEL, IMPERILED INNOCENTS: ANTHONY COMSTOCK AND FAMILY REPRODUCTION IN VICTORIAN AMERICA 4 (1997).

${ }^{132}$ NICOLA BEISEL, IMPERILED INNOCENTS: ANTHONY COMSTOCK AND FAMILY REPRODUCTION IN VICTORIAN AMERICA 148-49 (1997).

133 DAVID LANGUM, Crossing OVER THE Line: LEgISLATING MORALITY AND THE MANN ACT, 210 (1994); NICOLA BEISEL, IMPERILED INNOCENTS: ANTHONY COMSTOCK AND FAMILY REPRODUCTION IN VICTORIAN AMERICA 149 (1997); PAUL BOYER, URBAN MASSES AND MORAL ORDER IN AMERICA, 1820-1920, 133 (1978).

${ }^{134}$ NICOLA BEISEL, IMPERILED INNOCENTS: ANTHONY COMSTOCK AND FAMILY REPRODUCTION IN VICTORIAN AMERICA 79 (1997).
} 
argued for the abolition of marriage on account that it "enslaved" women and "demeaned" the very notion of love itself. ${ }^{135}$

By invoking the trope of slavery, Heywood and others countered Comstock's arguments about immorality - and harm - as it pertained to extra-marital sex, effectively subsuming both legal moralism and the harm principle within the larger rubric of promoting liberty. This emphasis on liberty provided just the type of alternate rhetorical structure to the morality/harm debate that we see in trafficking today - only it emerged a century ago. As historian Paul Boyer puts it, "[i]n the more lurid rhetorical flights of the antivice crusaders, to become a prostitute was to enter a life of 'white slavery'; from the perspective of many of the women themselves," however "the decision represented a liberating escape from bondage."136

At a time when African Americans were still considered inferior to whites, the invocation of white slavery proved a particularly powerful rhetorical trope aimed at mobilizing reform. ${ }^{137}$ For example, post-bellum labor leaders in cities like Chicago and St. Louis regularly associated America's industrial working class with white slavery, railing against industrial employers for treating their employees like chattel. ${ }^{138}$ As popular labor leader Eugene Debs put it in 1897, "the African slave” was a "prince" compared to white "workmen," who were not valued at "15 cents a cord by the slaveholders of today." 139

Just as labor leaders employed the rhetoric of white slavery to sanction reform, so too did reformers begin to argue that similar dangers threatened white working-class women. ${ }^{40}$ Beginning in the $1880 \mathrm{~s}$, for example, reformers in Chicago began to fear that "shop-girls, cigaretmakers [sic], and sewing girls" risked exploitation at the hands of unscrupulous employers who kept wages so low that women had no choice but to trade their chastity for money. ${ }^{141}$ Such fears escalated in the 1890s, fueled by sensational stories like H.H. Holmes's serial killing of

\footnotetext{
135 NICOLA BEISEL, IMPERILED INNOCENTS: ANTHONY COMSTOCK AND FAMILY REPRODUCTION IN VICTORIAN AMERICA 76, 87 (1997).

${ }^{136}$ Paul Boyer, URBan MAsses AND MORAL ORDER IN AMERICA, 1820-1920, 204 (1978).

${ }^{137}$ Helga Kristin Hallgrimsdottir \& Cecilia Benoit, From Wage Slaves to Wage Workers: Cultural Opportunity Structures and the Evolution of the Wage Demands of the Knights of Labor and the American Federation of Labor, 1880-1900, 85 SOCIAL FORCES 1393 (2007).

${ }^{138}$ Helga Kristin Hallgrimsdottir \& Cecilia Benoit, From Wage Slaves to Wage Workers: Cultural Opportunity Structures and the Evolution of the Wage Demands of the Knights of Labor and the American Federation of Labor, 1880-1900, 85 SOCIAL FORCES 1393 (2007); Mara L. Keire, The Vice Trust: A Reinterpretation of the White Slavery Scare in the United States, 1907-1917 35 JOURNAL OF SOCIAL HISTORY 5 (2001).

${ }^{139}$ Debs Army Quits Work, ChICAgO DAILY TRIBUnE, June 22, 1897, p. 7.

140 "White Slaves”: An Infamous Traffic Which England is Investigating, Chicago Tribune, Sept. 19, 1881, p. 8; An Infamous Traffic, ChiCAgo TriBune, July 8, 1885, p. 1. ${ }^{141}$ An Infamous Traffic, ChiCAGo TRIBUnE, July 8, 1885, p. 1
} 
women in Chicago during the 1893 World's Fair. ${ }^{142}$ Lurid accounts of immigrant women trafficked into slavery followed, further intensifying calls for legal reform. ${ }^{143}$ By, the close of 1907 Chicago journalist George Kibbe Turner had completed his torrid expose of prostitution dens run by depraved men who preyed on hapless, Jewish immigrant women. ${ }^{144}$ Countless white slavery narratives followed, ultimately leading Illinois Congressman James Mann to sponsor the White Slave Traffic Act, or Mann Act, in 1910. ${ }^{145}$

According to prevailing accounts, the Mann Act marked the convergence of at least two strains of thinking prominent at the turn of the Twentieth Century. ${ }^{146}$ The first held that immigrants from Central and Southern Europe were importing vice to the United States, both by bringing prostitutes to America and by establishing houses of prostitution in major cities in the United States. ${ }^{147}$ The second concern involved native-born American women drawn from rural towns to big cities for work, only to then find themselves lured into prostitution by unscrupulous men. ${ }^{148}$ The first concerted effort to link these demographic shifts to slavery emerged in George Kibbe Turner's exposes, positing that "a loosely organized association" of "Russian Jews" was responsible for staffing the city's houses of ill repute, first with immigrant girls and later with rural-born American girls who they "lured to brothels by false pretenses, or pricked by poisoned darts or hypodermic needles and then dragged off to dens of iniquity." 149

That concerns over white slavery emerged most strongly in the Midwest, argues David Langum, underscores the extent to which fears over white slavery may in fact have been linked less to fears of European

\footnotetext{
${ }^{142}$ ERIK LARSON, DEVIL In THE White City: Murder, MagiC, AND MADNESS AT THE FAIR THAT CHANGED AMERICA 6, 11 (2003).

${ }^{143}$ ERIK LARSON, DeVIL In THE White City: Murder, MagiC, AND MADNESS AT THE FAIR THAT CHANGED AMERICA 6, 11 (2003).

${ }^{144}$ DAVid LANGUM, Crossing OVER THE Line: LEGISLATING MORALITY AND THE MANN ACT 18 (1994).

145 DAVID LANGUM, Crossing Over the Line: Legislating Morality AND the MANN ACT 18, 24, 27 (1994).

${ }^{146}$ White-Slave Traffic (Mann) Act, Pub. L. No. 61-277, §2, 36 Stat. 825, 825 (1910) (codified as amended at 18 U.S.C. §2421-2424 (2006). The reference to slavery in the title of the Mann Act was removed in the 1940s. DAvid J. LANGUM, Crossing Over THE LiNE: LEGISLATING MORALITY AND THE MANN ACT 242 (1994).

${ }^{147}$ DAVID J. LANGUM, CROSSING OVER THE LINE: LEGISLATING MORALITY AND THE MANN ACT 242 (1994).

148 DAVID J. LANGUM, CROSSING OVER THE Line: LEGISLATING MORALITY AND THE MANN ACT 242 (1994); Christopher Diffee, Sex and the City: The White Slavery Scare and Social Governance in the Progressive Era, 57 AMERICAN QUARTERLY 416 (2005); Ethan A Nadelmann, Global Prohibition Regimes: The Evolution of Norms in Intenational Society, 44 INT’L ORG. 479 (1990).

${ }^{149}$ LANGUM, CROSSING OVER THE LINE, 27.
} 
immigration than to domestic concerns. ${ }^{150}$ Among these concerns were demographic shifts away from rural areas and into cities, coupled with the erosion of traditional moral values in urban centers. ${ }^{151}$ For example, single women in cities found themselves free from traditional patterns of courtship, often mixing with men who expected sex in return for companionship, nights on the town, and access to urban entertainment. ${ }^{152}$ Such "charity girls" troubled rural conservatives precisely because they challenged conventional morals, raised the specter of women's liberation, and arguably undermined the normative appeal of marriage itself. ${ }^{153}$ Put simply, the Mann Act employed the rhetoric of freedom to keep women under control.

While scholars of the Mann Act have focused heavily on its race and gender implications; few have underscored the law's significance to the legal rhetoric of criminal law, particularly its use of slavery to counter and/or accentuate claims rooted in legal moralism and harm. ${ }^{154}$ For example, reformers began to reframe prostitution as white slavery at the turn of the century partly to override the question of whether single women who engaged in extra-marital sex might have done so willingly, for their own pleasure. ${ }^{155}$ Such "charity girls” suffered criticism for going "out with men for an evening of pleasure and drink and intercourse where no money is asked or offered."156

As social conservatives struggled to reign in urban youth, the Mann Act became a popular prosecutorial tool - partly because it criminalized men who transported women "for immoral purposes," thereby obviating the question of whether those women might have actually wanted to travel. Further, the law's invocation of liberty helped it transcend fundamental problems with legal moralism, including the question of what, precisely, constituted an immoral purpose. As legal

${ }^{150}$ Christopher Diffee, Sex and the City: The White Slavery Scare and Social Governance in the Progressive Era, 57 AMERICAN QUARTERLY 416 (2005); LANGUM, CROSSING OVER THE LINE, 253-54.

${ }^{151}$ LANGUM, CROSSING OVER THE LINE, 253-54.

${ }^{152}$ White-Slave Traffic (Mann) Act, Pub. L. No. 61-277, §2, 36 Stat. 825, 825 (1910) (codified as amended at 18 U.S.C. §2421-2424 (2006).

${ }^{153}$ LANGUM, CROSSING Over THE LiNe, 125.

${ }^{154}$ To be clear, scholars have discussed the white slave traffic scare as a discursive episode "which acted as a condenser of anxieties about shifting race, sex, and gender relations." See e.g., Cecily Devereux, "The Maiden Tribute" and the Rise of the White Slave in the Nineteenth Century: The Making of an Imperial Construct, 26 VICTORIAN Review 3 (2000). See also DAVID LANGUM, CROSSING OVER THE Line: Legislating MORALITY AND THE MANN ACT (1994)(underscoring the political motivations behind the act); Brian Donovan, White Slave Crusades: RaCe, Gender AND ANTI-VICE ACTIVISM (2006) (emphasizing the law's role in constructing racial categories); FREDERICK K. GRITTNER, WHITE SLAVERY: MYTH, IDEOLOGY, AND AMERICAN LAW (1990).

${ }^{155}$ Deals in White Slaves: Philadelphia Syndicate has Branches in Europe, CHICAGO TRIBUNE, Nov. 21, 1902, 4.

${ }^{156}$ DAVID LANGUM, CROSSING Over THE Line: LEgISLATING MORALiTY AND THE MANN ACT 121 (1994). 
historian Ariela Dubler has demonstrated, the Mann Act did not reflect shared morals so much as it provided prosecutors with a tool for delineating what precisely constituted "licit and illicit sexual expression." ${ }^{\text {W57 }}$ Initially deemed anything outside of marriage, prosecutors gradually began to look within marriage as well, particularly after prostitutes began to employ the "marriage cure" by betrothing their pimps. ${ }^{158}$ Given natural disagreements over morality, in other words, the Mann Act benefited substantially from its association with anti-slavery rhetoric, which all parties endorsed. Consequently, "[b]etween the end of Prohibition and the mid-1940s," notes historian David Langum, "the Mann Act vied for second place in federal convictions," only "trailing behind interstate transportation of stolen vehicles." 159

Then, abruptly, things changed. ${ }^{160}$ The act began to lose support in the late 1940s and early 1950s, partly due to a shift in attitudes towards private sexual behavior on the part of American elites, and partly due to evolving attitudes about race that made appeals to ending white slavery politically gauche. ${ }^{161}$ For example, the Supreme Court indicated as early as 1938 that the federal government might be constitutionally authorized to protect civil rights abuses against African Americans in southern states. ${ }^{162}$ President Harry Truman redoubled these efforts following World War II, establishing a committee to investigate civil rights abuses in 1946. ${ }^{163}$ By 1949, national tolerance for overt racism had declined sufficiently to warrant an amendment to the title of the Mann Act, deleting any mention of white slavery. ${ }^{164}$

Though slavery's color fell from view, support for the freedom principle did not, as evidenced by a spike in concern over trafficking in the

${ }^{157}$ Ariela Dubler, Immoral Purposes: Marriage and the Genus of Illicit Sex 115 Yale L. J. 756 (2006).

${ }^{158}$ Ariela Dubler, Immoral Purposes: Marriage and the Genus of Illicit Sex 115 Yale L.

J. 784 (2006).

${ }^{159}$ DAVID LANGUM, CROSSING Over the LiNE: LegisLATING Morality AND THE MANN ACT 168 (1994).

${ }^{160}$ LANGUM, Crossing Over THE Line, 222. Protection of Children Against Sexual Exploitation Act of 1977, Pub. L. No. 95-225, 92 Stat. 8-9 (signed into law January, 1978). 18 U.S.C. $\$ 2421$.

${ }^{161}$ Though popular during the Progressive Era, the Mann Act suffered a decline in support over the course of the Twentieth Century. Yet, the statute lived on. In 1978, for example, Congress amended the law to better define "immoral purpose," including an explicit reference to "sado-masochistic abuse." In 1986, however, Congress jettisoned such terms, limiting the offense to anyone who transported an individual across state lines for the purpose of engaging in "any sexual activity for which any person can be charged with a criminal offense," including trafficking. Protection of Children Against Sexual Exploitation Act of 1977, Pub. L. No. 95-225, 92 Stat. 8-9 (signed into law January, 1978). 18 U.S.C. §2421.DAVID LANGUM, CROSSING OVER THE LINE: LEGISLATING MORALITY AND THE MANN ACT 219 (1994).

${ }^{162}$ Missouri ex rel. Gaines v. Regents, 305 U.S. 337 (1938).

${ }^{163}$ DAVID MCCULLOUGH, TRUMAN 586-89 (1992).

${ }^{164}$ David Langum, Crossing OVER the Line: Legislating Morality and the ManN ACT 219 (1994). 
1940s and 50s. For example, the same year that "white slavery" was deleted from the Mann Act, President Truman signed the first United Nations Convention for the Suppression of the Traffic in Persons and of the Exploitation of the Prostitution of Others into law, a bill that invoked the rhetoric of trafficking to target international and domestic prostitution. ${ }^{165}$ For example, Article 1 of the Convention required signatories to "punish any person" who "procures, entices, or leads away," any woman for "purposes of prostitution." "166 As liberal reformers began to push for the deregulation of vice in the 1960s and 70s, however, interest in trafficking subsided. ${ }^{167}$ It wasn't until moral conservatives seized on the rhetoric of trafficking to fight prostitution in the 1980s that it began to draw popular attention, a move that carried into the 1990s when President Clinton led negotiations over a new U.N. Trafficking Protocol in $1998 .{ }^{168}$ That December, the United Nations General Assembly passed a resolution establishing an "intergovernmental ad hoc committee" to discuss proposals for quelling international "trafficking in women and children." ${ }^{169}$ Subsequently, the Committee met in Austria in 1999 to consider draft proposals from member states, including a draft protocol to the Convention against Transnational Organized Crime that included a provision on trafficking. ${ }^{170}$ One year later, the Committee approved a final draft and sent it to the General Assembly for approval. ${ }^{171}$ In a symbolic move, the Assembly agreed to meet in Palermo, Sicily - "the epicenter of the old Italian Mafia" - to sign the final document. ${ }^{172}$

All one hundred seventeen signatories of the Treaty agreed to make "trafficking in persons" a criminal offense. To avoid delay, Congress drafted the 2000 Victims of Trafficking and Violence Protection Act, or TVPA, authorizing the federal government to prosecute violations

\footnotetext{
${ }^{165}$ CONVENTION FOR THE SUPPRESSION OF THE TRAFFiC IN PERSONS AND OF THE EXPLOITATION OF THE PROSTITUTION OF OtHERS, APPROVED BY THE GENERAL ASSEMBLy REs. 317 (IV), Dec. 2, 1949.

${ }^{166}$ Janie Chuang, Rescuing Trafficking from Ideological Capture: Prostitution Reform and Anti-Trafficking Law and Policy, 158 PENN. L. ReV. 1667, fn 36 (2010).

${ }^{167}$ Martti Lehti \& Kauko Aromaa, Trafficking for Sexual Exploitation, 34 CRIME AND JUSTICE 1 (2006).

${ }^{168}$ Janie Chuang, Rescuing Trafficking from Ideological Capture: Prostitution Reform and Anti-Trafficking Law and Policy, 158 PENN. L. REV. 1666-667 (2010).

${ }^{169}$ General Assembly Res. 53/111 §10, U.N. Doc. A/RES/53/111 (Jan. 20, 1999); Gen. Assembly Ad Hoc Comm. on the Elaboration of a Convention Against Transnational Organized Crime, Draft Protocol to Combat International Trafficking in Women and Children Supplementary to the United States Convention on Transnational Organized Crime: Proposal Submitted by Argentina, U.N. Doc. A/AC.254/8 (Jan. 15, 1999), available at http://daccess-ddsny.un.org/doc/UNDOC/GENAT99/43/PDF/V9980243.pdf).

${ }^{170}$ Britta Loftus, Coordinating U.S. Law on Immigration and Human Trafficking: Lifting The Lamp to Victims, 43 Colum. HuM. RTS. L. REV. 143 (2011).

${ }^{171}$ Britta Loftus, Coordinating U.S. Law on Immigration and Human Trafficking: Lifting The Lamp to Victims, 43 Colum. Hum. RTS. L. REV. 143 (2011).

${ }^{172}$ Britta Loftus, Coordinating U.S. Law on Immigration and Human Trafficking: Lifting The Lamp to Victims, 43 CoLUM. HuM. RTS. L. REV. 143 (2011).
} 
of the treaty as trafficking in labor or sex. ${ }^{173}$ Ironically, even as conservatives derided the introduction of foreign law to the United States, few protested America's participation in the UN protocol on trafficking. ${ }^{174}$ On the contrary, political interest in trafficking rose dramatically in the United States, leading not only to federal involvement in enforcement but also to unprecedented amounts of public and private funds for antitrafficking initiatives, despite questionable evidence that rates of trafficking had actually risen. ${ }^{175}$

In a manner that might be relevant to understanding Ed Bagley’s plight, Kansas City, Missouri became a national hub of trafficking prosecutions following enactment of the TVPA in 2000, in part due to the "innovative techniques" of its prosecutors. ${ }^{176}$ In 2009, for example, Cynthia Cordes became the first federal prosecutor to "successfully prosecute customers of the sex trade under anti-trafficking laws" by setting up elaborate stings ${ }^{177}$ By 2011, the Department of Justice sanctioned a "pilot program" in Kansas City aimed at providing the resources necessary for prosecuting sex trafficking cases "from St. Louis to western Kansas."178 That Ed Bagley was aware of the "innovative" prosecutions taking place just north of his trailer is unlikely, perhaps explaining his failure to anticipate any problems with the maintenance of a 24 year-old white slave.

\section{CONCLUSION}

As this Article has sought to demonstrate; the prosecution of Ed Bagley for maintaining a sex slave in rural Missouri points to new, even strange directions for the law of trafficking. ${ }^{179}$ Initially conceived as a measure to prevent the forced transportation of women across international borders, the law has since morphed into a much more

\footnotetext{
${ }^{173}$ Britta Loftus, Coordinating U.S. Law on Immigration and Human Trafficking: Lifting The Lamp to Victims, 43 Colum. HuM. RTS. L. REV. 143, 155 (2011).

${ }^{174}$ Britta Loftus, Coordinating U.S. Law on Immigration and Human Trafficking: Lifting The Lamp to Victims, 43 Colum. HuM. RTS. L. REV. 143, 155 (2011).

${ }^{175}$ Kristen Hinman, Lost Boys: New Research Demolishes the Stereotype of the Underage Sex Worker - and Sparks an Outbreak of Denial Among Child-Sex-Trafficking Alarmists Nationwide, VILlAGE VoICE, Nov. 2, 2011

${ }^{176}$ Ron Sylvester, Prosecutor Shares Tactics for Fighting Sex Trafficking in Kansas, WICHITA EAGLE, www.kansas.com, Aug. 30, 2011.

${ }^{177}$ Ron Sylvester, Prosecutor Shares Tactics for Fighting Sex Trafficking in Kansas, WiCHITA EAGLE, www.kansas.com, Aug. 30, 2011.

${ }^{178}$ Ron Sylvester, Prosecutor Shares Tactics for Fighting Sex Trafficking in Kansas, WiCHITA EAGLE, www.kansas.com, Aug. 30, 2011.

${ }^{179}$ It is important to note here that Bagley's case is not the only case where trafficking has been used to prosecute D/s couples, it is just a particularly demonstrable case for how those prosecutions rely neither on legal moralism or the principle of harm. see United States v. Marcus, 487 F. Supp. 2d. 289, 292 (2007).
} 
expansive tool for regulating private relationships. ${ }^{180}$ In Bagley’s case, for example, there is considerable evidence that his relationship to "slave nicole," as she identified herself in Taboo magazine, was consensual both before and during a trip to California for a pornographic photo shoot in 2007 - even though that trip then became the focal point for much of Bagley's trafficking charge, not to mention a separate Mann Act charge as well. ${ }^{181}$

That the government decided to proceed with only minimal evidence of coercion - which is required by the trafficking statute - tells us something new about the rhetorical justifications for federal prosecution, in particular the harm principle. Long ascendant in criminal law, the harm principle has repeatedly been used to deregulate private sexual behavior between consenting adults. ${ }^{182}$ Indeed, the decision to make coercion a requirement in the federal crime of sex trafficking reflects the extent to which the harm principle animated the law's legislative intent. ${ }^{183}$ Yet, in Bagley's case the government moved beyond that principle, ignored evidence of consent, and relied on a very different rhetorical justification for prosecuting the defendant - the abolition of consensual slavery. ${ }^{184}$ As John Stuart Mill noted in 1859, even individuals who acquired consenting slaves could be regulated; for slavery violated the "principle of freedom.",185

Long forgotten by criminal law scholars, Mill's freedom principle provides a rhetorical justification for the criminal sanction that transcends claims rooted in either morality or harm. ${ }^{186}$ Also, it is not new. As this article shows, the government's decision to charge Bagley not just with trafficking but also the Mann Act helps to underscore the role that the freedom principle has traditionally played in American criminal law. Initially styled the White Slave Traffic Act, the Mann Act emerged during a time in American history when reformers sought desperately to control young single women, "charity girls” who left rural areas for big cities only to trade their pastoral virtue for the allure of urban vice. ${ }^{187}$ Neither appeals to morality nor harm proved as electric as invocations of slavery when it came to regulating the men who exploited such women, pointing to a longstanding, if lost pillar of legal rhetoric, a counter to legal moralism and the harm principle rooted in Mill's notion of freedom and individuality. ${ }^{188}$

\footnotetext{
180 See supra §I.

181 See supra $\S$ I.

${ }^{182}$ Bernard E. Harcourt, The Collapse of the Harm Principle, 90 J. OF CRIMINAL LAW AND CRIMINOLOGY 109 (1999).

18318 U.S.C. $\$ 1591$.

184 See supra §II.

185 JOHN STUART MiLL, ON LIBERTY 101 (1859, Indianapolis: Hackett, 1978).

${ }^{186}$ Russell Hittinger, The Hart-Devlin Debate Revisited, 35 AM. J. JuRIS. 52 (1990) citing JOHN STUART MiLL, ON LIBERTY 9 (Hackett, ed. 1978).

187 See supra §I.

188 See supra §I.
} 